generation weather radar, were selected to provide the United States with maximum coverage for severe weather and floods. Advance warnings of major tornadoes could be as much as 30 minutes, because Doppler radars allow forecasters to see inside storms for the first time.
Maximum operational reliability and efficiency will be attained by concentrating the forecasting staff at the Weather Forecast Offices, which will be associated with the NEXRAD radars. The existing National Weather Service office sites will be consolidated into this new national network.

\title{
25 years ago $\ldots$
}

The June 1964 BulletiN* contained the dinner address given under the following title by Prof. J. Bjerknes at the annual meeting in Los Angeles in January 1964. We give here only the first four paragraphs of that address.

\section{Half a Century of Change in the "Meteorological Scene"}

The "meteorological scene" at the beginning of our century had separate centers of activity, largely out of touch with each other. There was no world-wide communication system for weather data, and daily weather maps were of more local extent than today. The weather forecasting in each area was troubled by the lack of early information about travelling disturbances from the west. It did not help the European weather forecasters, for instance, that transatlantic cablegrams could bring a daily summary of the North American weather. That had been tried in the early years of the cable connection, but then again abandoned. The Atlantic gap had proved too wide to be bridged by interpolation on the weather maps, and radio messages from ships could not yet be contemplated.

Upper-air observations were in their first stage of development and exerted no influence on the routine of daily forecasting. Manned balloon flights were a popular public spectacle; and the measurement of the close-to-moist-adiabataic rate of decrease of temperature with height was an important scientific by-product of such flights. Unmanned balloon flights with self-recording instruments had penetrated still higher than the manned ones, and had discovered the stratosphere.

The people on the "scene of theoretical meteorology" were becoming aware of the interesting three-dimensional structure of the atmosphere, and began to look for tools from the science of hydrodynamics that could put weather forecasting on a scientific foundation. The old German genius of natural science, von Helmholtz, had already two decades before 1900 made the first important steps with his theorems of circulation of incompressible media; and my father, Vilhelm Bjerknes, had followed up at the turn of the century by extending Helmholtz' theorems to compressible media (like air) on a rotating planet.

My first childhood memories date from this period. The tapping of the typewriter in my father's study was heard year in and year out. But then also, during summer vacations in the country, a different activity took place. Impressive kites, far greater than the toy ones, were launched, carrying recording instruments. My role was of course only to watch while grown-up students operated the kites; and the purpose of the whole thing was far beyond my comprehension. As I later learned, the kite ascents were made to extend aerological knowledge northwards from Central Europe, where many balloon ascents had taken place, to the virtually unexplored Scandinavia. In technical terms, the ascents were made to count the isobaric-isoteric solenoids in a meridional profile. The new circulation theorems called for such field work. But I must add, as most of you know, that my father's tinkering with kite technology never caused the sensation on the meteorological scene as did the circulation theorem itself.

\section{0 years ago $\ldots$}

\section{Climatology and Political Geography*}

\author{
SAMUEL VAN VALKANBURG
}

Prof. of Geography, Clark University, Worcester, Mass.

The strongest nations have been built in the temperate zones, and many of the problems of those nations arise from climate conditions.

The colonial problem, for instance, is not to be dismissed with a wave of the hand as being more a matter of present than future history. Colonies may be economic and political wings of temperate zone nations for a long time to come, because climate has made natives of the average colony less energetic than the natives of the colonizing state.

Some nations have geographical problems within themselves. Our Civil War was a fight between peoples influenced economically by different climates. Spain has a long record of internal troubles. Spain has a wide variation in climate.

England keeps her great empire of peoples under different climates together by allowing increasing amounts of self-autonomy. The United States will bind more closely if a certain amount of regional independence in relation to climatic differences is encouraged.

Nations have cycles of life much as do persons, animals and plants. Nations are born, become adolescent, then mature, and finally die.

Working in this process are climate and geography, the economics of the nation's citizens, the race, language, religions and government of those citizens, and their colonial system.

Look about the world today. Old nations being reborn? There's China, and Spain. The Italy of Mussolini and the Germany of Hitler one might regard now as adolescent nations.

Then we have the mature nations such as England and the United States, France and the Scandinavian lands. In these lands democracy is successful because patterns have been established and citizens have been educated in citizenship over a period of years.

Last come the nations that die of weakness, lack of energy to defend themselves. As these nations flop a dictator usually arises out of the very nature of the events-such as Rivera in Spain. The dictator may fall, to make way for one under whom the nation starts a new cycle of life, as may be the case under Chiang Kai-Shek in China.

For world order the mature nations should protect the younger and older nations, guide the adolescent nations, but not run the show, as do the parents in a family.

If the young and adolescent nations will not take discipline, the parent or mature nations should be equipped to spank them into an orderly international life.-Quoted from report in the Kansas City Star, June 11, 1938, p. 2.

\footnotetext{
* Notes on a lecture to the Kansas City Meeting, June 10, 1938.
} 